\title{
Effectiveness of Murottal Therapy in Reducing Anxiety in Diabetics
}

\author{
Siti Nur Asiyah ${ }^{1 *}$, Imamah Istikhomah ${ }^{1}$ \\ 1)Faculty of Psychology and Health in UIN Sunan Ampel Surabaya \\ nurays72@yahoo.co.id \\ DOI: DOI: http://doi.org/10.29080/ihsp.v3i2.223
}

Received: September 2019, Accepted: September 2019, Published : September 2019

\section{Keywords}

Murottal

Anxiety,

Diabetes

Mellitus

\begin{abstract}
The purpose of this study was to determine the effectiveness of murottal AlQur'antherapy in reducing anxiety in people with diabetes mellitus. This research is quantitative research with experimental methods that use data collection techniques in the form of anxiety scale. Subjects in this study amounted to 15 people who underwent in a patient at RSUD dr. H. Slamet Martodirdjo Pamekasan with criteria of people with diabetes mellitus who have high anxiety. Selection of subject by giving an anxiety scale to everyone with diabetes mellitus who is undergoing hospitalization in hospitals in October. The results of the scale calculation and then made the norm with the formula interval to categorize the anxiety of high and low. Of the 15 people who were selected to be the subjects of the past research will undertake the murottal Al-Qur'an treatment. The result is effective in reducing anxiety in people with diabetes mellitus.
\end{abstract}

\section{Introduction}

Diabetes mellitus (DM) is still a national problem and is listed in the 4th rank of national research priorities for degenerative diseases after cardiovascular, cerebrovascular, and geriatric diseases. According to the World Health Organization (WHO), Indonesia is the 4th largest number of people with diabetes mellitus after United States, India and China(1). Based on the estimation of the International Diabetes Federation (IDF), there are 81 million people with diabetes in the Southeast Asian region. This number is expected will increase from $7,0 \%$ in the age group $20-79$ years in 2010 to 8,4\% in 2030 (2). WHO predicts an increase in the number of people with DM in Indonesia from 8,4 million in 2000 to 21,3 million in 2030. IDF estimates there will be an increase in the number of people with diabetes mellitus from 7,0 million in 2009 to 12,0 million in 2030. Data from WHO and IDF show differences in prevalence rates. However, the second report shows an increase in the number of people with diabetes as much as 2-3 times in 2030(2). Brunner (2002) states that the number of diabetes mellitus patients is 5\% -10\% DM of type 1 and $90 \%$ 95\% DM of type 2(3).

According to the 2013 Health Profile of East Java Province, Diabetes Mellitus (DM) is a noncommunicable disease and included in 10 most inpatient diseases in East Java after hypertension (2). According to Suyono (2009), the prevalence of DM of type 2 in East Java Province is 1,43\% - 1,47\%. With a population of East Java province of approximately 38.052.950 people, it is estimated that there are 544.157-559.378 people with DM of type 2 in East Java (4). The increase in the number of patients with DM of type 2 also occurs in RSUD dr. H. Slamet Martodirdjo located on Jl. Raya Panglegur No. 04, District of Pamekasan. Based on data from RSUD dr. H. Slamet Martodirdjo obtained data on the number of type 2 diabetes mellitus patients undergoing hospitalization in July, August and September 2017 reaching 120 people.

Diabetes Mellitus (DM) of type 2 is a chronic disease that requires lifelong therapeutic intervention. Interventions for diabetes mellitus can be done by controlling glucose within normal limits. This disease causes sufferers for life, so it can potentially cause anxiety for sufferers of physical, psychological, social and environmental health (5). For example, worries about high blood glucose levels, anxiety(6) about complications due to diabetes, anxiety about work, harmony in marriage, etc. As the results of research conducted by David (2004) that there are 48\% of diabetics who experience anxiety due to their illness (7). When someone knows that he is a person with diabetes mellitus, there will be many changes that occur in 
his life. For example, there is fear, anxiety, panic, anger, and even those who rebel against the conditions they experience. This phenomenon shows that DM deserves attention, especially in East Java, which has a high prevalence of DM. This anxiety, if not handled properly, can lead to more complicated problems in managing DM disease (6).

One way to overcome anxiety is music therapy which can improve physical and psychological wellbeing. Hariati (2010) states that when music is activated, all areas associated with the limbic system will be stimulated to produce feelings and expressions. In addition to music therapy, another sound therapy that is proven to reduce anxiety is therapy of murottal Al-Qur'an. The results of the research conducted by Dr. Al Qadhi, president director Dr. Al Qadhi, director of the Islamic Medicine Institute for Education and Research in Florida, United States, about the effect of listening to the holy verses of the Qur'an in humans towards physiological and psychological perspectives. The results of the study show that listening to the verses of Qur'an can cause enormous physiological and psychological changes. This study explains that listening to the Holy Qur'an affect bringing calm and reducing reflective nerve tension (8).

The results of other studies conducted by DR. Ahmad al-Qadhi who wanted to know the influence of the Qur'anic verses on human physiological conditions also proved that the Qur'an was able to reduce nervous (physiological) tensions. The study was conducted on five non-Muslim volunteers, the age range between 17-40 years, using the MEDAQ 2002 (Medical Data Quotient) type stress measuring device, which was equipped with software and electronic detector systems. The results of the study showed positive results that were listening to the Holy Qur'an had a significant influence on reducing the tension of $(9)$ reflective nerves (9).

This is reinforced by the results of Abdurrochman's research (10) that the Qur'anic stimulant can be used as relaxation therapy even better than stimulant music therapy because the stimulant of the Qur'an brings up delta waves of $63.11 \%$ of music therapy. The increase in delta waves also reached the highest percentage of 1,057\%. The Qur'anic stimulus often brings up delta waves in the frontal and central regions on the right and left the side of the brain. This could be happening because the frequency of the recitation of the Qur'an has the ability to reprogram brain cells, improve their strength and balance them.

Based on the description above, the researcher felt interested in knowing more about murottal AlQuran therapy as one of the therapeutic choices in reducing anxiety levels. More specifically, the aim of this study is to determine the effectiveness of therapy of Murottal al-Quran in reducing anxiety in type 2 diabetes mellitus sufferers.

\section{Method}

The sample of this study were 15 respondents using purposive sampling technique who w undergoing inpatient care at RSUD dr. H. Slamet Martodirdjo, Pamekasan Regency. This study was a quasiexperimental study using the design of one group pretest-posttest design. The design of the pretest can be described as follows:

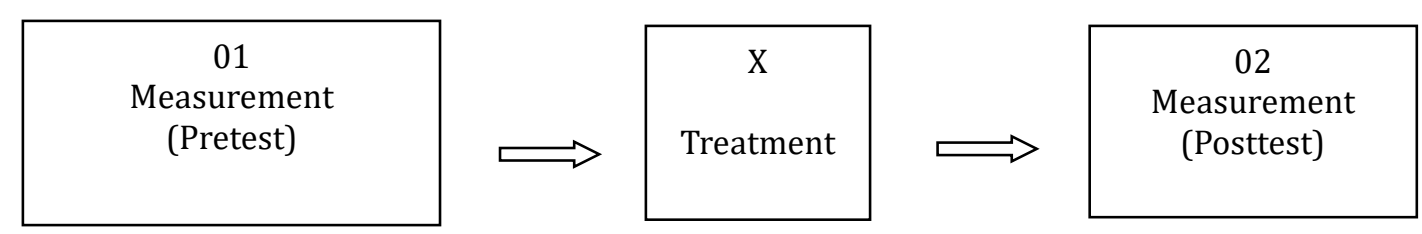

Picture 1 Pretest - Postest Design

Information:

01 : patient anxiety before treatment (Pretest).

02 : patient anxiety after treatment (Posttest).

X: Therapy of Murottal al-Quran.

\section{Result}

The results of this study descriptively, the anxiety level of the subjects before and after murottal therapy treatment can be seen in the following table : 
Table 1. Anxiety Level Before and After Therapy of Murottal Al-Qur'anin Patients with DM of Type 2 in RSUD dr. H. Slamet Martodidjo Pamekasan

\begin{tabular}{ccc}
\hline NO & Before & After \\
\hline 1 & 124 & 85 \\
2 & 115 & 80 \\
3 & 118 & 84 \\
4 & 125 & 82 \\
5 & 119 & 82 \\
6 & 124 & 88 \\
7 & 121 & 83 \\
8 & 119 & 82 \\
9 & 121 & 79 \\
10 & 126 & 85 \\
11 & 122 & 82 \\
12 & 122 & 85 \\
13 & 114 & 78 \\
14 & 118 & 83 \\
15 & 118 & 80 \\
\hline
\end{tabular}

The above table is known that all of the respondents were decrease from before and after the treatment of therapy of murottal Al Quran.

Table 2. The mean level of anxiety in Paired Samples Statistics

\begin{tabular}{|l|l|l|l|l|l|}
\hline \multicolumn{2}{|c|}{} & \multicolumn{1}{|c|}{ Mean } & N & Std. Deviation & $\begin{array}{c}\text { Std. Error } \\
\text { Mean }\end{array}$ \\
\hline \multirow{2}{*}{ Pair 1 } & Before intervention & $1.2040 \mathrm{E} 2$ & 15 & 3.54159 & .91443 \\
\cline { 2 - 6 } & After intervention & 82.5333 & 15 & 2.64215 & .68220 \\
\hline
\end{tabular}

Subjects who experienced anxiety before being given a therapy of murottal al-Quran had a mean of 1.2040, and subjects who had been given murottal al-Quran therapy had a mean of 82.5333. The standard deviation of each who have not been given a therapy of murottal Al-Qur'an is 3.54159, and those who have been given therapy of murottal Al-Qur'an of 2.64215. While the standard error of mean for those who have not been given therapy of murottal Al -Qur'an is 0.91443 , and those who have been given the therapy of murottal Al-Qur'an are 0.68220 .

The results explained that the value of anxiety after being given Murottal Al-Qur'anTherapy is lower than before being given Therapy of Murottal Al-Qur'an. This shows that the Therapy of Murottal AlQur'anis effective in reducing anxiety in people with diabetes mellitus of type 2.

The results of the analysis using the t-test, differences in anxiety levels in people with diabetes mellitus of type 2 between before and after being given therapy from Murottal Al-Qur'anin the table below.

Table 3. Paired Sample Test

\begin{tabular}{|c|c|c|c|c|c|c|c|c|c|}
\hline & \multirow{3}{*}{ Mean } & \multirow{3}{*}{$\mathrm{N}$} & \multirow{3}{*}{$\begin{array}{c}\text { Std. } \\
\text { Deviation }\end{array}$} & \multirow{2}{*}{\multicolumn{2}{|c|}{$\begin{array}{c}\text { Paired Differences } \\
95 \% \text { Confidence } \\
\text { Interval of the } \\
\text { Difference }\end{array}$}} & \multirow{3}{*}{$\mathrm{t}$} & \multirow{3}{*}{$\mathrm{Df}$} & \multirow{3}{*}{$\begin{array}{l}\text { Sig. (2- } \\
\text { tailed) }\end{array}$} \\
\hline & & & & & & & & & \\
\hline & & & & & Lower & Upper & & & \\
\hline Pair 1 & $\begin{array}{l}\text { Before/ } \\
\text { After }\end{array}$ & 3.78667E1 & 2.66905 & .68914 & 36.38860 & 39.34474 & 54.947 & 14 & .000 \\
\hline
\end{tabular}

From the table above, it can show that the anxiety level of patients with type 2 diabetes mellitus between before and after being given treatment in the form of Therapy of Murottal Al-Quran is significantly different, which is indicated by a significant number of $0,000<0,005$. 


\section{Discussion}

People with diabetes mellitus of type 2 have a level of anxiety related to the disease and treatment to be taken and the occurrence of serious complications. Anxiety can occur related to the management of therapy that must be diet or eating arrangements, an examination of blood sugar levels, consumption of drugs and also exercise. Besides, the risk of disease complications can be experienced by sufferers also causes anxiety Anxiety can lead to worsening health conditions or diseases suffered by a person with diabetes. Anxiety experienced by people with type 2 diabetes mellitus in addition to complicating therapy, can also inhibit the ability of their activities in everyday life.

This research has proven that therapy of murottal Al-Qur'an is effective for reducing anxiety levels in patients with diabetes mellitus of type 2. The results of this study are in line with Dr.Al-Qadhi research at the Florida Large Clinic in the United States, which has proven that listening to reading the verses of the Qur'an, can cause enormous physiological changes. In general, they feel a decrease in the level of anxiety, depression, sadness, and feeling peace of mind. From the results of the study, it was concluded that the Qur'anic reciting had a significant effect of up to $97 \%$ in causing peace of mind and healing of diseases. Likewise, with the research conducted by a Dutch psychologist, Professor Vander Hoven (2002) who announced his new findings of the effect of reading the Al-Qur'anand the repeated pronunciation of the word "ALLAH" in both patients and healthy people. The study was conducted on subjects for three years. The results of the study concluded that Muslims who read the Quran regularly could prevent psychological and physiological disease.

Siswantinah (2011) (11) explains that murottal is an Al-Qur'an sound recording that is mixed by a qori '(the reader of the Qur'an). The chanting of the Qur'an physically contains elements of the human voice, while the human voice is an amazing healing instrument and the most accessible tool to reach. Siswantinah (2011) (11) explains that murottal is a recorded voice of the Qur'an by a Qori '(the reader of the Qur'an). The reciting of the Qur'an physically contains elements of the human voice, while the human voice is an amazing healing instrument and the most accessible instrument. Sound can reduce stress hormones, activate natural endorphins, increase feelings of relaxation, and divert attention from fear, anxiety and tension, improve the body's chemical system so that it lowers blood pressure and slows breathing, heart rate, pulse and brain wave activity. Deeper or slower breathing rates are very good at causing calm, emotional control, deeper thinking and better metabolism.

Therapy of Murottal Al-Qur'anor Al-Qur'anrecitation with regular rhythm and correct reading is also Al-Qur'anmusic capable of bringing calm and minimizing anxiety $97 \%$ for those who hear it $65 \%$ get peace from Al recitation -Qur'an and 35\% get the order from reading in Arabic, not Al-Qur'an(12).

According to (8) with the therapy of murottal, the quality of one's awareness of God will increase, both people know the meaning of the Qur'an or not. This awareness will cause the totality of submission to Allah SWT. In this state, the brain is in alpha waves, is a brain wave at a frequency of $7-14 \mathrm{~Hz}$. This is an optimal brain energy state and can get rid of stress and reduce it. In a calm state, the brain can think clearly and can do contemplation about the existence of God. It will form coping or positive expectations in patients.

Heru (13) explained that the benefits of listening to the verses of the Qur'an are:

a) Listening to reading the verses of the Qur'an with the tartil will get peace of mind.

b) Reading the Qur'an physically contains elements of the human voice. The human voice is an amazing healing instrument and the most accessible instrument. Sound can reduce stress hormones, activate natural endorphins, increase feelings of relaxation, and divert attention from fear, anxiety and tension, improve the body's chemical system so that it lowers blood pressure and slows breathing, heart rate, pulse and brain wave activity. Deeper or slower breathing rates are very good at causing calm, emotional control, deeper thinking and better metabolism.

\section{Conclusion}

Based on the results of the study it can be concluded that the therapy of muratttal Al-Quran is effective in reducing the level of anxiety in people with diabetes millitus (DM) of type 2 in RSUD dr. H. Slamet Martodidjo Pamekasan.

\section{References}

1. P.E.R.K.E.N.I. Konsensus Pengelolaan dan Pencegahan Diabetes Mellitus Tipe 2 Di Indonesia. Jakarta; 2011.

2. Depkes. Dari Penyakit Menular ke Tidak Menular. [serial online]. diakses. In: tanggal 6 Oktober [Internet]. 2014. Available from: http://www.pppl.depkes.go.id 
3. Brunner. Buku Ajar Keperawatan Medikal-Bedah. Terjemahan oleh Kuncara Y. Jakarta: EGC; 2002.

4. Suyono S, dkk. Pelaksanaan Diabetes Mellitus Terpadu. Jakarta: FKUI; 2009.

5. Copel. Psychiatric and Mental Health Care: Nurse's Clinical Guide. In USA: Lippicottwilliams; 2007.

6. Hastuti SA. Faktor-faktor Resiko Ulkis Diabetika pada Penderita Diabetes Mellitus. Tesis. Surakarta: Program Studi Ilmu Keperawatan Fakultas Kedokteran Universitas Diponegoro Semarang. 2008.

7. Murdiningsih DS dkk. Pengaruh Kecemasan Terhadap Kadar Glukosa Darah Pada Penderita Diabetes Melitus di Wilayah Puskesmas Banyuanyar. Surakarta; 2013.

8. Faradisi. Firman.2012.Efektivitas Terapi Murottal dan Terapi Musik Klasik Terhadap Penurunan Tingkat Kecemasan Pasien Pra Operasi di Pekalongan.

9. Badri MS. A study of measuring the critical factors of quality management. 1995;2(36-53):10-1108.

10. R M, T. M C. Pengaruh Pembacaan dan Pemaknaan Ayat- ayat Al-Qur'anterhadap Penurunan Kecemasan pada Santriwati.

11. Deby N. P,.2014.Pemberian Terapi Murottal Terhadap Penurunan Tingkat Kecemasan Pada Asuhan Keperawatan Tn.K dengan Pre Operasi Fraktur Collum Femur Sinestra Diruang Mawar RSUD Dr.Soedirman Mangun. Surakarta: Sekolah Tinggillmu Kesehatan Kusuma Husada;

12. S W. Terapi Murotal Al-Qur'anSurat Arrahman Meningkatkan Kadar $\beta$ - Endorphin dan Menurunkan Intensitas Nyeri pada Ibu Bersalin Kala I Fase Aktif.

13. Heru. Rukyah Syar'i Berdasarkan Kearifan. In 2008. Available from: http://trainermuslim.com/feed/rss 